\title{
The power of science and truth: countering paid liars' efforts to influence tobacco policy
}

The article by Montini and Bero ${ }^{1}$ in this issue of Tobacco Control provides sound insights and sane counsel for tobacco control advocates. There are also intriguing hints of benevolent bias, which bodes well for advocates in sympathetic societies, but a cautionary note for those seeking strong regulation in more tobacco industry friendly political environments.

Let me begin with the good news for the cynical. Regulatory decision makers-at least in some parts of the USA - those unelected civil servants who have the power to implement regulatory laws by developing either weak or potent regulations, really do pay attention to science and truth. For tobacco control advocates, it pays to participate in the regulatory process: it pays to prepare testimony and written commentary with great care. It pays to learn how to present data in ways that are both convincing and readily digestible.

It also pays to lean heavily upon unimpeachable authority, especially government and quasi-governmental bodies, such as the Surgeon General, the Centers for Disease Control, the National Institutes of Health, the Environmental Protection Agency, the Federal Trade Commission, the National Institute for Occupational Safety and Health, and the National Academy of Sciences. For these regulators, the weight of the authority cited compounds the weight of the underlying data.

And this good study holds amply deserved bad news for the tobacco industry, its lawyers, and its experts - money does not buy you the goodwill or good opinion of such regulators. The more lawyers you bring with you, the less credibility your witnesses have. The more you pay the scientists who support your position, and publish their findings in captive, non-peer reviewed journals (the glossy printed proceedings of industry sponsored conferences, say, rather than $\mathcal{F A M A}$ or Tobacco Control), the more sceptical the regulators become. I once clerked for a federal district judge known for his bluntness, who called all expert witnesses, "paid liars". Regulators seem to harbour the same bias.

And these regulators display a good, healthy bias toward tobacco companies to begin with: "not credible from the get-go"; "always come with mobs of lawyers". They vow that they have no interest "in listening to Joe Carton complain". This is the attitude which the regulators surveyed bring to their task of sorting out truth from sophistry.

All good news, and it comes with good advice, especially the importance of choosing as witnesses scientists who are effective advocates. We do not need as witnesses even superb researchers who, paraphrasing James
Joyce, live a short distance from comprehensible language, display arrogance, disdain non-scientists, and become intoxicated with the endless recitation of arcane data. Instead, the authors affirm, we need scientist witnesses who are capable of effective "self presentation", who frame the proposed regulation as moderate, reasonable, centrist, in simple terms, and who adopt "formats that can be absorbed".

Most scientists I know shun the compound label "scientist-advocate". But the research makes very clear that the most effective witnesses are precisely that: both deeply credentialed and scrupulous scientists and artful advocates. These are rare, but the likes of Ken Warner, Jeff Harris, Stan Glantz, Witold Zatonski, and others testify that they do exist!

\section{A linguistic quibble}

I have a minor but not insignificant linguistic quibble with the authors, and a cautionary note for advocates in jurisdictions in which tobacco control is less developed.

First, my quibble: I would not have referred to the subjects of this article as "policy makers". I may be overly sensitive here, since, as a regulator for many years at the Federal Trade Commission (FTC), I was constantly rebuked by hostile legislators for the sin of "making policy", rather than faithfully seeking to implement the policies enacted into law by Congress.

More than a quibble, I also have reservations about the appropriately cautious observation by the authors that "there are enough parallels between the regulatory and legislative processes to generalise findings". As a staff member of the US Senate Commerce Committee for a dozen years, I had the often unsettling opportunity to observe more than 100 hearings and their legislative aftermaths. I might be able to recall just one or two in which scientific testimony changed any votes. What they ordinarily achieved was to provide a public umbrella for the Senators' pre-ordained political party, ideological, geographic, or campaign contributor bias. Thus the invariably shoddy and transparent testimony of the tobacco lobbies' scientists nonetheless provided welcome cover for the tobacco state senators and those others whose campaigns were enriched by Big Tobacco's largess.

I have nothing but admiration for the regulators surveyed, but I do have an uncomfortable confession to make, which might temper the reassurance that the survey offers: I was a regulator at the FTC; I was bound by the law to base my decisions on solid evidence. I tried. But I also know that I started many hearings on 
proposed regulations with a strong predilection and it would be the rare occasion in which any testimony reversed that predilection. I suspect that the regulators interviewed were not so different in that regard from me. Perhaps if the state regulators had been from tobacco growing Kentucky and North Carolina, or were among the pro-business regulatory appointments of the current Bush Administration, the answers might well have been different-or the same, but less honest!

Challenges in less developed countries I worry too about regulators in less developed countries. Our experience working with advocates in central and eastern Europe is unsettling. Government officials, even health officials, do not distrust tobacco company representatives automatically, as do most developed country regulators.

This means, as some of the authors respondents warn, that such regulators may be especially vulnerable to those industry "red herrings" and "finely honed" sophistry that our best regulators-armed by our best advocates - scorn. The "Liberalni Institute" in Prague presents itself as an independent body of economic experts who have determined, independently, that a Czech Republic advertising ban would virtually destroy the country's economy. The very fine print that acknowledges that Philip Morris graciously contributed to the research, and the report's slavish recitation of cooked data and shallow argument that puppets all the arguments long discredited in the US and western Europe, does not prevent the Czech newspapers from treating the report as scientific revelation. Able Czech tobacco control advocates seek to respond, but they lack the public relations resources to get equal attention. Consequently, the understanding and attitudes of national policy makers, legislators, and regulators alike are distorted.

In other less developed countries, the industry's paid liars challenge the applicability of health data compiled in other countries, as if tobacco's toll on the lungs and heart somehow halted at the national border. Of course, the tobacco companies know that many poorer nations simply cannot afford the exhaustive country specific epidemiology that the industry's political friends self righteously insist upon.

Thus at this moment in the global struggle against tobacco, the advocates in these countries most need the support of the very scientist advocates that the authors justly celebrate.

Perhaps the soundest of the regulators insights, and the authors' counsel, is that "tobacco control advocates should also work behind the scenes in order to balance the pressure applied by industry representatives". This means lobbying legislatures directly and through skilful media advocacy. For in the end, the best, "most upright" regulator and legislator is one who receives at least as much pressure from the public health advocates as from industry lobbying. He or she is then most free to pay serious attention to the scientific evidence well wrought and persuasively presented.

The Advocacy Institute,

MICHAEL PERTSCHUK

Washington $D C$,

USA

mpertschuk@advocacy.org

1 Montini T, Bero LA. Policy makers' perspectives on tobacco control advocates' role in regulation development. Tobacco Control 2001;10:218-24.

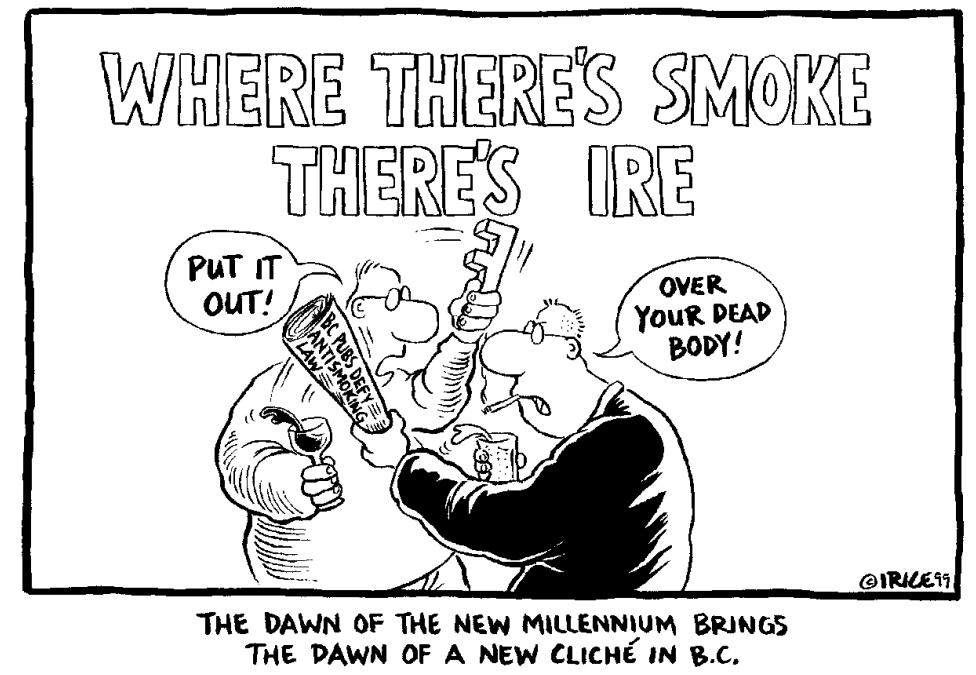

(C) Ingrid Rice. 